\title{
Assessment of wetland potential and bibliometric review: a critical analysis of the Ramsar sites of India
}

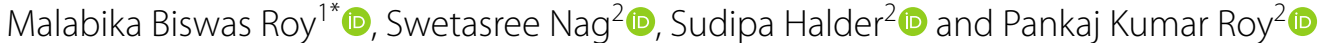

\begin{abstract}
Background: This study focussed on effective bibliometric analysis of research on Ramsar sites in India within the last 30 years using VOS viewer software. The study focused on the estimation of the current areal extent and meteorological impact on wetland together with bibliometric analysis. The online data source of Web of Science has been used to extract all the relevant documents on Indian Ramsar sites published within a period of 1989 to 2020.

Main body: The main objective is to analyze the trend of research on the Indian Ramsar site both qualitatively and quantitatively. The peak of research growth has been lifted after the twentieth century as most of the Indian water bodies have been designated or put into the land from this period. A geographical location-based mapping was prepared based on the number of publications during the study period to observe the growing research interest in wetland studies in India. The highest publications have been documented on East Calcutta Wetland located in West Bengal followed by Loktak Lake in Manipur, Deepor Beel in Assam and others. The most frequently used keywords were "Ramsar site", "India", "wetland", "wetlands", "remote sensing" etc. India published most of the documents on wetland studies in the Indian context. England, Australia, Canada also had various international collaborative works with Indian researchers.
\end{abstract}

Conclusions: The research output shows an upward research trend on Indian Ramsar sites both quantitative and qualitatively. Such kind of research can provide a panoramic view towards the worldwide research trend and help to generate further effective approaches for the betterment of our environment.

Keywords: Ramsar sites, Bibliometric analysis, Web of Science, VOSviewer, Research trend

\section{Background}

Wetlands are considered as a unique ecological unit, which contributes enormous goods and services to human society (Prasad et al. 2002). It also consists of rich biodiversity and states, as the most valuable natural resource on the earth (Whitehouse et al. 2008). They are the invaluable resources of the environment, resource potential ecology and biodiversity in India (Biswas Roy et al. 2016). Globally the areal extent of wetlands accounts

\footnotetext{
*Correspondence: malabikabiswasroy@gmail.com

${ }^{1}$ Department of Geography, Women's College, Calcutta, Kolkata, West Bengal, India

Full list of author information is available at the end of the article
}

for about 12.1 million $\mathrm{km}^{2}$ showing diverse characteristics in its geographical locations, dominant species, soilwater chemistry etc. Such productive natural resources can also be well utilised by several landless people of rural India, where pisciculture activity is very dominant (Biswas Roy et al. 2016). Not only that, several other environmental benefits like flood management, groundwater recharge, water supply, irrigational activities are also well practiced in wetland areas. In this regard to gain international importance Ramsar Convention on wetlands has been signed in the year of 1971 to conserve and augment the ecological functions of wetlands. In India, only 37 wetlands are designated as Ramsar sites (MoEFCC 2020). Environmental education and awareness is required to 
symbolise the Ramsar Convention to stop the vulnerability of inland wetlands of the world (Shah and Atisa 2021). Since the time of the Ramsar Convention numerous researchers have made studies on water pollution control, water quality management, biodiversity conservation, wetland ecosystem services, its socio-economic valuations etc. (Brix 1994; Mitsch and Gosselink 2007; Zhang et al. 2010; Biswas Roy et al. 2012). Lal (2008) stated that restoration of wetlands around the world is highly needful to maintain the atmospheric carbon cycle of our ecosystem. Apart from this, several review papers have also been published on wetland studies. Bassi et al. (2014) studied the overall wealth of wetlands in Indian context to outline the major threats on wetland management. Zhang et al. (2010) also carried out a bibliometric research on wetland studies to show potential guidance towards future researchers on wetland research.

\section{Ramsar convention on wetland}

The Ramsar Convention mainly aims to conserve the worldwide degradation of wetlands and to conserve it through wise use and sustainable management. It is an intra-governmental treaty that supports national action (Chandra et al 2021). The entire task requires international cooperation, policy framing capacity building and technical know-how transfer It is one of the foremost treaties to enrich the ecosystem approach towards conservation and the whole habitat is conserved as a single unit and system (Griffin and Ali 2014). In this era of climate change and urbanisation, the conservation techniques include protection and management of sites, the conductance of scientific studies, creating funding opportunities, encouraging ecotourism (Gardner et al. 2008).

\section{Importance of Ramsar areas}

Ramsar areas are important for human growth and survival. These areas are the world's most productive environments and reservoirs of biological diversity which supply water and essential products upon which numerous species of plants and animals thrive. The Convention of the areas requires the restriction of encroachment and loss of wetlands now and in the future (Davidson 2016).

\section{Main text}

Ramsar sites are the social-ecological system that focuses on demographic, socio-political, cultural and economic factors that indices biotic and abiotic factors to retrieve (Kingsford et al. 2021). In the recent days the risk of wetland in Ramsar sites will increase with the global warming and sea level rise (Xi et al. 2020). Given on this background, the present paper attempts to study worldwide research trend on Ramsar sites in India which are very much threatened by various human-induced factors mainly land use changes, infrastructural development, industrialisation etc. (Zhang et al. 2010; Zedler and Kercher 2005; Rawat 2018). Here wetland potential of the Ramsar sites in India has been a witness and a bibliometric analysis method has been used to investigate the status of research on internationally recognised wetlands areas in India within a period from 1989 to 2020, which can give an outline to formulate better strategies for overall environmental restoration.

\section{Data source and methodology}

In this study, the online data source of Web of Science has been used to produce qualitative and quantitative research analysis on studies related to Ramsar sites in India. On 18th July, 2020, the online database of Web of Science has been accessed to gather all the publications on Ramsar sites within a time of 1989 to 2020. The database has been searched under the topic of "Ramsar sites in India", where about 103 publications have been detected. Various types of documents have been retrieved from such an online platform of data sources where articles are the dominant ones.

Finally, the bibliometric information of all the documents has been extracted and analysed in form of document types, language, location wise publication variability, annual trend analysis in total publication and citation, distribution of journal based on the subject area, keyword analysis and productive country analysis and productive institutions.

A couple of network analysis has been performed using VOSviewer software (Van Eck and Waltman 2010) to generate linkages between every aspect of data analysis. To analyse the areal water potential of the wetland in India database has been downloaded from the different governmental and non-governmental websites and then combined and presented in a tabular format.

\section{Results and discussions \\ Areal extent analysis of Ramsar sites in India}

The wealth of the wetland ecosystem in India is enormously enriched with diverse flora and fauna. The wetlands of India play an important role in providing ecological services and goods to a greater extent of the society. Rapid urbanisation, industrialization and agricultural extension have been leading to the decrease in the areal extent of the wetlands. But from the last few years, management and conservation of the wetlands have got the highest attention in the national water sector (Bassi et al. 2014). According to the Ramsar Convention water bodies such as the rivers, lakes, coastal lagoons, mangroves, peat land, coral reefs are considered natural and water bodies such as the ponds, farm ponds, 


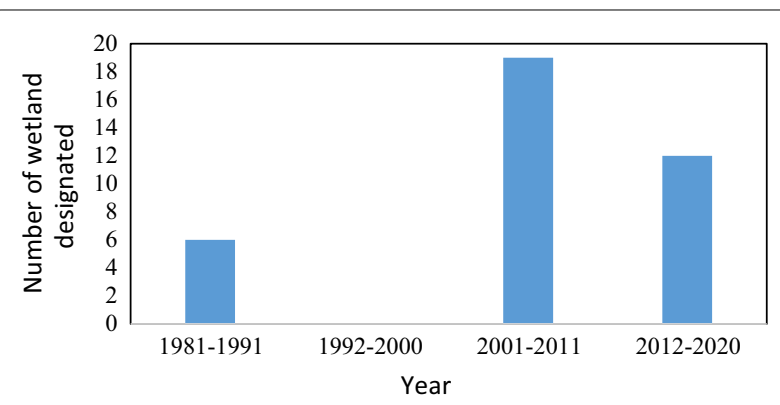

Fig. 1 Number of Wetland designated in Ramsar sites

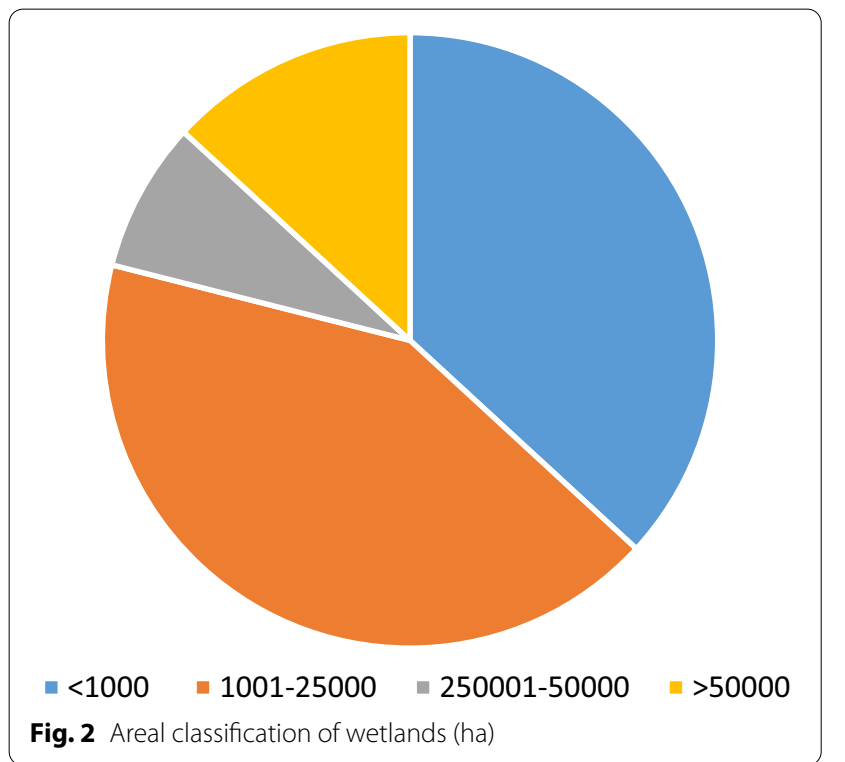

irrigated fields, sacred groves, salt pans, reservoirs, gravel pits, sewage farms and canals are considered manmade are included wetland ecosystem of India. The following figures (Figs. 1, 2) show the potential of wetland in India and their areal extent. Sundarban has the highest wetland area of 423,000 hectares (ha), which is also one of the world heritage sites designated by UNESCO providing livelihood to thousands of villagers. Following Sundarban, the top 4 wetlands of India in terms of areal extent are Vembanad-Kol Wetland (151,250 ha), Chilka wetland $(116,500$ ha), Kolleru lake (90,100 ha) and Bhitarkanika Mangrove (65,000 ha).

Wetlands of India has been designated as the Ramsar site in different time of the year since the nineteenth Century. The number of wetlands designated as the Ramsar site at different time has been shown with help of the cartographic representation (Fig. 1) (Ramsar 2020, https://rsis.ramsar.org/). From the list of 37 wetland designation years of each has been classified into the four-time period that is 1981-1991 (6), 19922000 (0), 2001-2011 (19) and 2012-2020 (12). From Fig. 1, it can be seen that the highest time (49\%) of designation is from 2001 to 2011 which signifies the period when more attention towards conservation and sustainable development of the wetland has been looked upon. This period also witnessed the beginning of the water crisis both surface and groundwater throughout the world. Of the 37 wetland areas classification (ha) has also been and has been divided into 4 classes that is $<1000 \quad(14), 1001-25,000$ (16), 250,001-50,000 (3) and $>50,000$ (5) (Fig. 2). The highest number of the wetland is found under the areal extent of 1001-25,000 ha. In recent years areal extent of wetlands is decreasing because of the climate change with greater intensity of drought, which leads to drying of surface water bodies (https://www.ramsar.org/).

\section{Present situation of wetlands in India}

Hindukush and Himalayan mountain ranges play an important role in the spatial and temporal inconsistency in precipitation and temperature aspects of the tropical and sub-tropical regions of Asia including India. Most of the rivers of India is fed the melting glaciers and the deposition of huge sediment can be seen at the mouth of the rivers. This climatic variability and the geomorphic diversity have led to the enrichment of the wetlands in India. Based on the climatological aspects and drought intensity in India, it can be concluded that the eastern and central part of India (West Bengal, Madhya Pradesh, Konkan, Bihar and Orissa), the frequency of drought is one in five years. Whereas, drought occurs once every four years in the parts of southern Karnataka, eastern Uttar Pradesh and Vidarbha region (Nath et al. 2017) (Fig. 3). In the area where the intensity of the drought is higher, chances of the drying up of the wetlands are common (Fig. 4). Figure 3 signifies the intensity of drought is higher in the south, central and eastern parts of India. Wetlands located in those zones are the most vulnerable. The areas where the drought intensity is high will lead to the drying of both the surface and groundwater zone. Low precipitation will also lead to a decrease in the groundwater recharge over the region. The low precipitation together with the drying of the surface water bodies leading to the exploitation of groundwater. This led to alteration of the hydrological regime of wetlands which are associated with the aquifers and has made significant deterioration of their ecological characteristics (Froend et al. 2016). From both Figs. 3 and 4, it can be witnessed the Kolleru wetland is located within the drought-prone zone thereby requiring sustainable management otherwise it will lead 


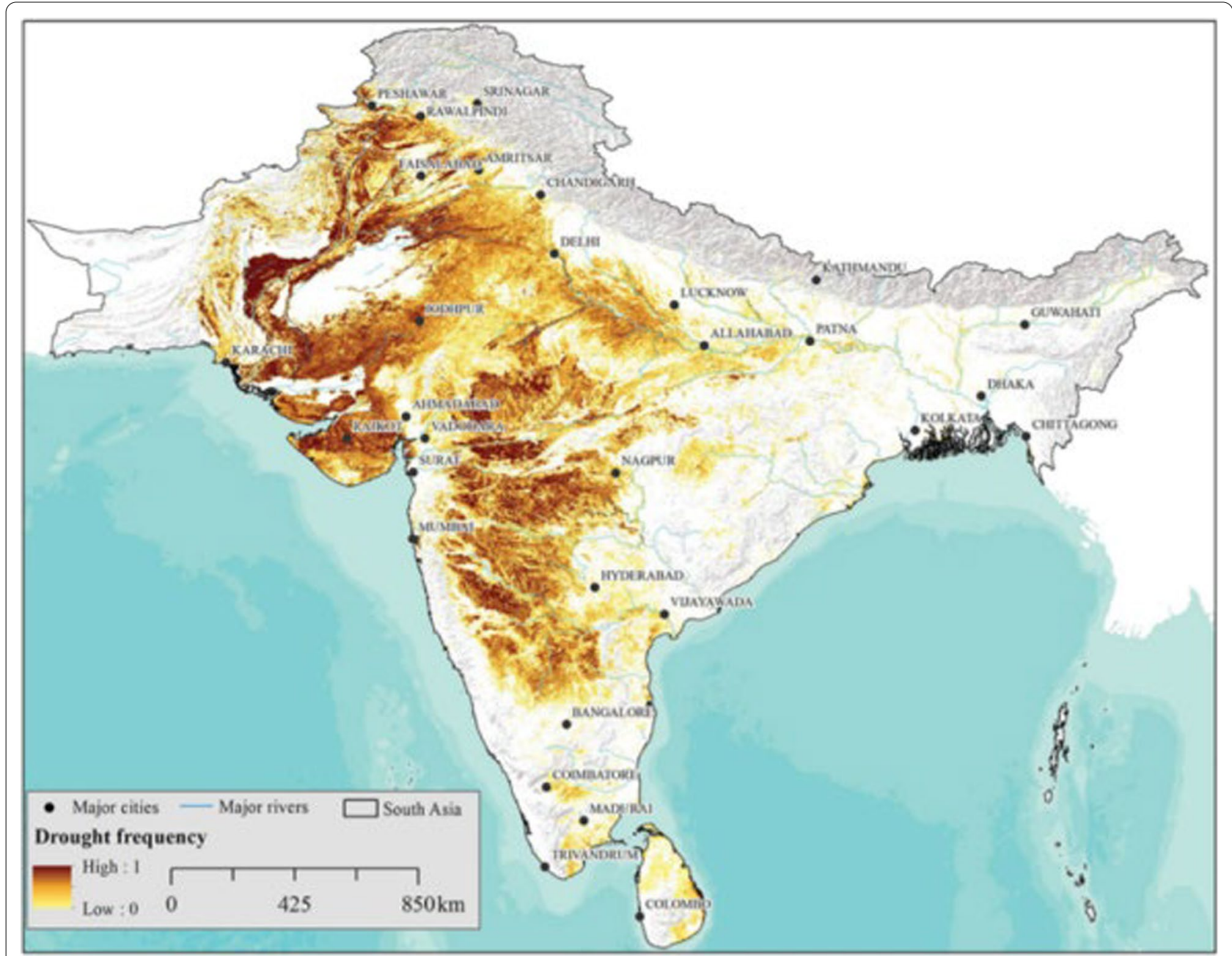

Fig. 3 Drought prone regions of India. Source: https://www.iwmi.cgiar.org/

to the degradation of the ecological and societal character of the wetland.

\section{Research potentiality of different Ramsar sites in India}

The study reveals different Ramsar sites in India have their own importance level based on which research work has been carried out to reveal their potentiality on our environment. 24 Ramsar sites have been considered in this study to show their research potentiality based on some physical and non-physical criteria. Within 30 years, most of the research work has been carried out on East Kolkata Wetland which was known as a renounced Ramsar sites of India. This site acts as a Kidney that flushes out the wastewater coming from Kolkata metropolitan city. For such reason, the maximum number of research work has been found under the theme of water quality assessment followed by the health of the aquatic ecosystem of this wetland (Fig. 5). Besides this, work on soil quality has also been made on this wetland. Here a large extent of agricultural practices is met by using the wastewater which alters the soil properties and reduces the carbon sequestration hence some research work has been carried out. Under the theme of bio-diversity assessment, research work has been done on several Ramsar sites namely Bhitarkanika, Bhoj wetland, Chilka wetland, Keoladeo, Sundarban etc. Of which the studies on Bhoj wetland are the most predominant. In the valuation of the aquatic ecosystem, Deepor wetland, Kolleru wetland, Sambhar Lake and Sundarban are mostly assessed. Other than such physical criteria, various human-induced factors are also responsible for the deterioration of various Ramsar sites. Rudrasagar Lake, Sambhar Lake and Wular Lake which were known for its rich flora and faunal species and play a major role in maintaining the hydrological balance, have been threatened by various anthropogenic activities. For example, in Harike wetland polluted untreated industrial wastewater is disposed into 


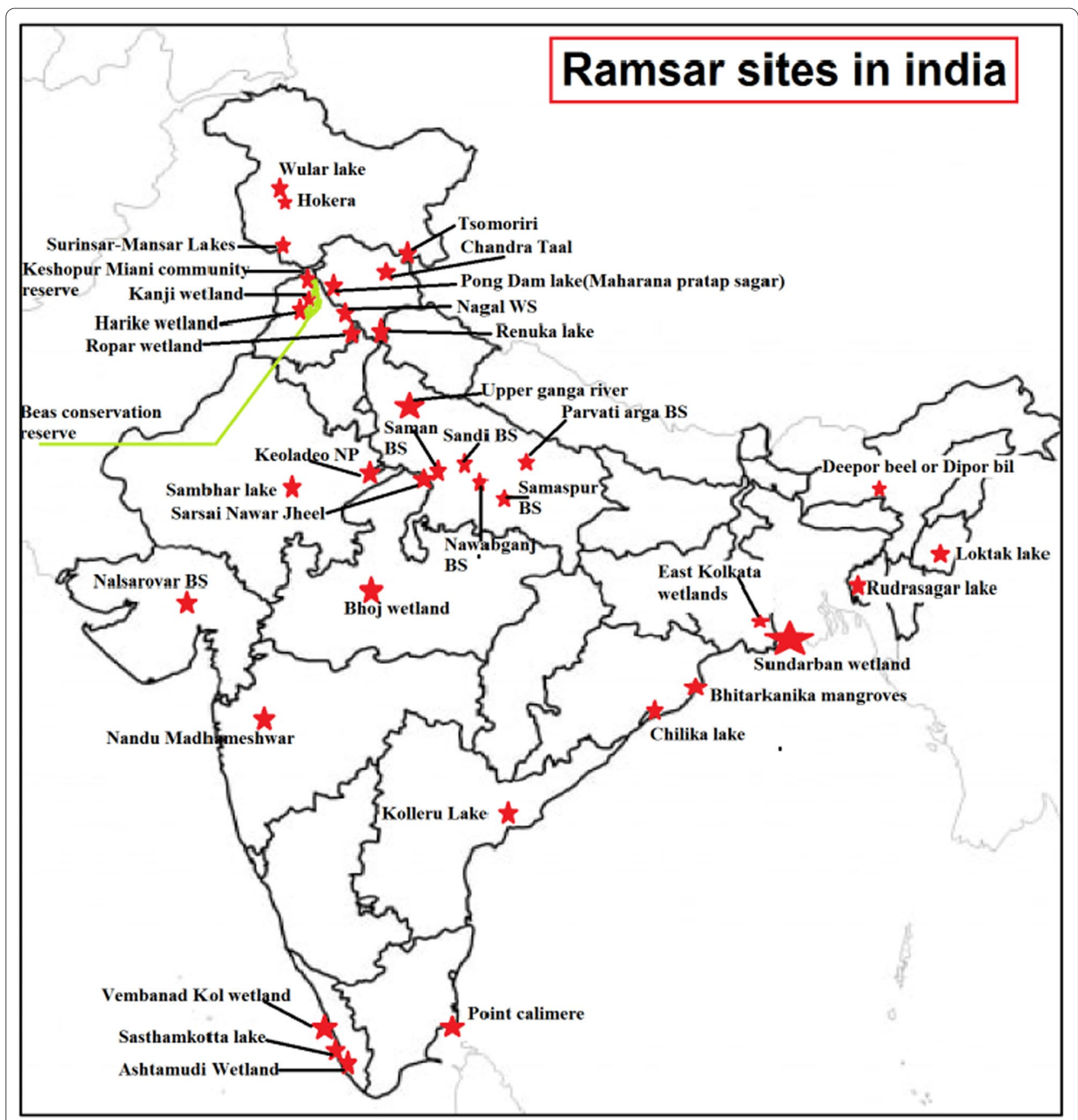

Fig. 4 Major Wetlands of India (National Wetland Conservation Programme)

the wetland site which degrades its ecological health and destroyed the natural beauty affecting the eco-tourism of that site.

Such kinds of studies are very much beneficial to find out the environmental threats of the Ramsar sites based on which various researchers and policy makers can undertake various sustainable conservation measures accordingly. 


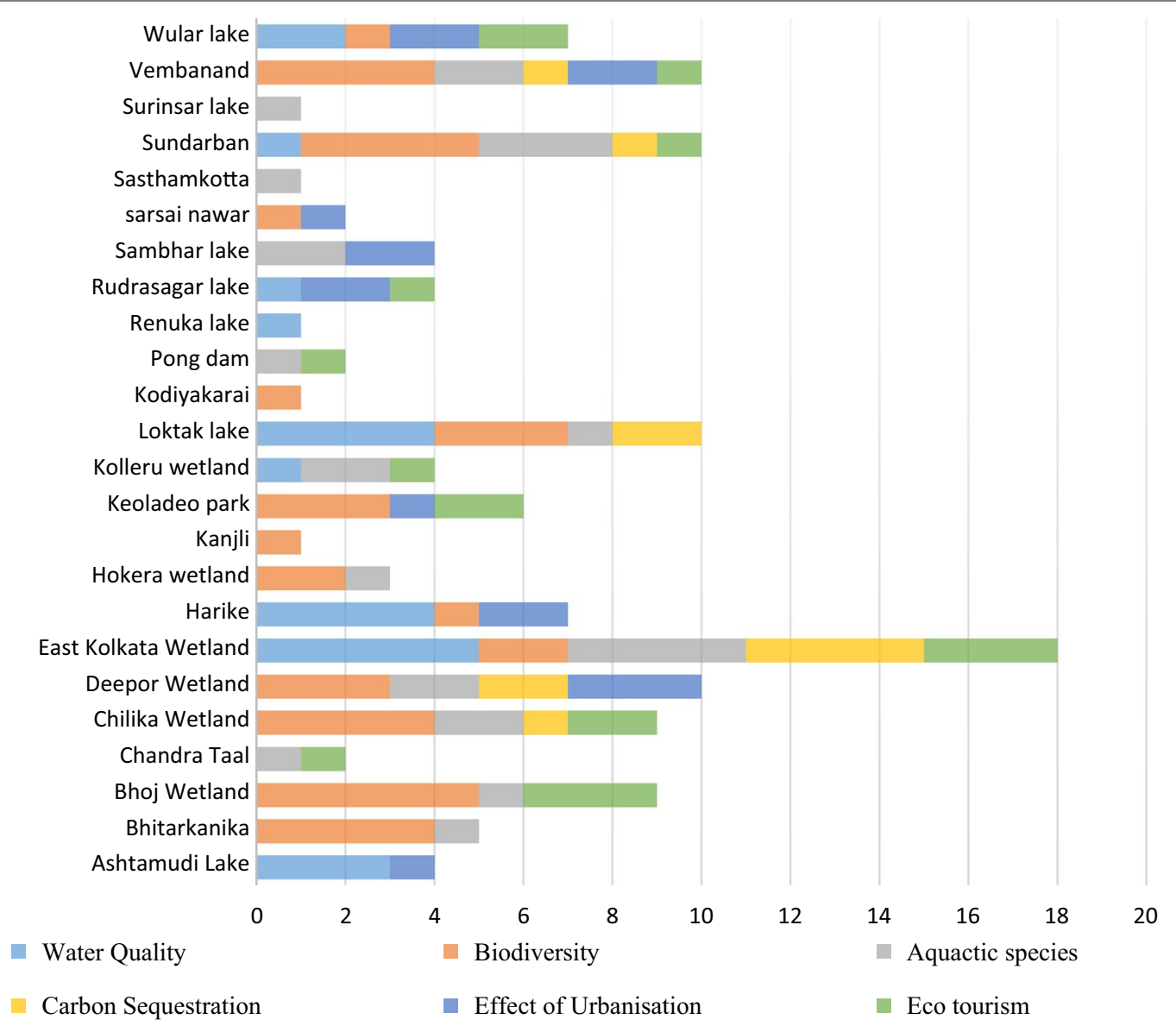

Fig. 5 Number of major research areas on Ramsar sites of India

\section{Bibliometric analysis of Ramsar sites in India Document types, language and distribution}

From the online database platform of Web of Science, about 103 publications have been rectified within a time span of 30 years. Among them, articles were the dominant ones comprising $98.06 \%$ of the total publications. Whereas the other ones like proceeding papers $(0.97 \%)$ and review articles $(0.97 \%)$ were less significant to the total publications. All the documents have been published in English language as it is being highly preferred by most of the journals related to wetland studies (Hsieh et al. 2004; Chen et al. 2005). This kind of analysis can help to identify the most influential documents in any field of research. Within these databases, it has been observed that very few bibliometric research analysis were done on the studies related to Ramsar sites in India.

For this reason, authors have grouped all the extracted documents into different Ramsar location in India and shown the location wise varying research interest with the help of cartographic representation. Figure 6 shows, that within time period of 30 years East Calcutta Wetland in West Bengal has gained maximum research interest in wetland studies. About 18 publications were identified based on water purification, conservation and management of East Calcutta wetland area. Following this Loktak Lake in Manipur having 11 research works, Deepor Beel in Assam with 10 number and Vembanad wetland in Kerala has also received 10 research works from the year 1989 to 2020. Such kind of analysis can provide the idea about priority research area among the researchers within a specific period.

\section{Characteristics of publication outputs}

Figure 6 shows the year wise total publications with their total citation score on studies related to the Ramsar site in India, which have been categorized under Web of Science online database. The graph shows both in terms of publication and citation, the growth period has started from the year 2004 (Fig. 7). Before that, no publication has been documented in Web of Science category based on Indian Ramsar site research. The international Ramsar Convention which has been established in the year of 


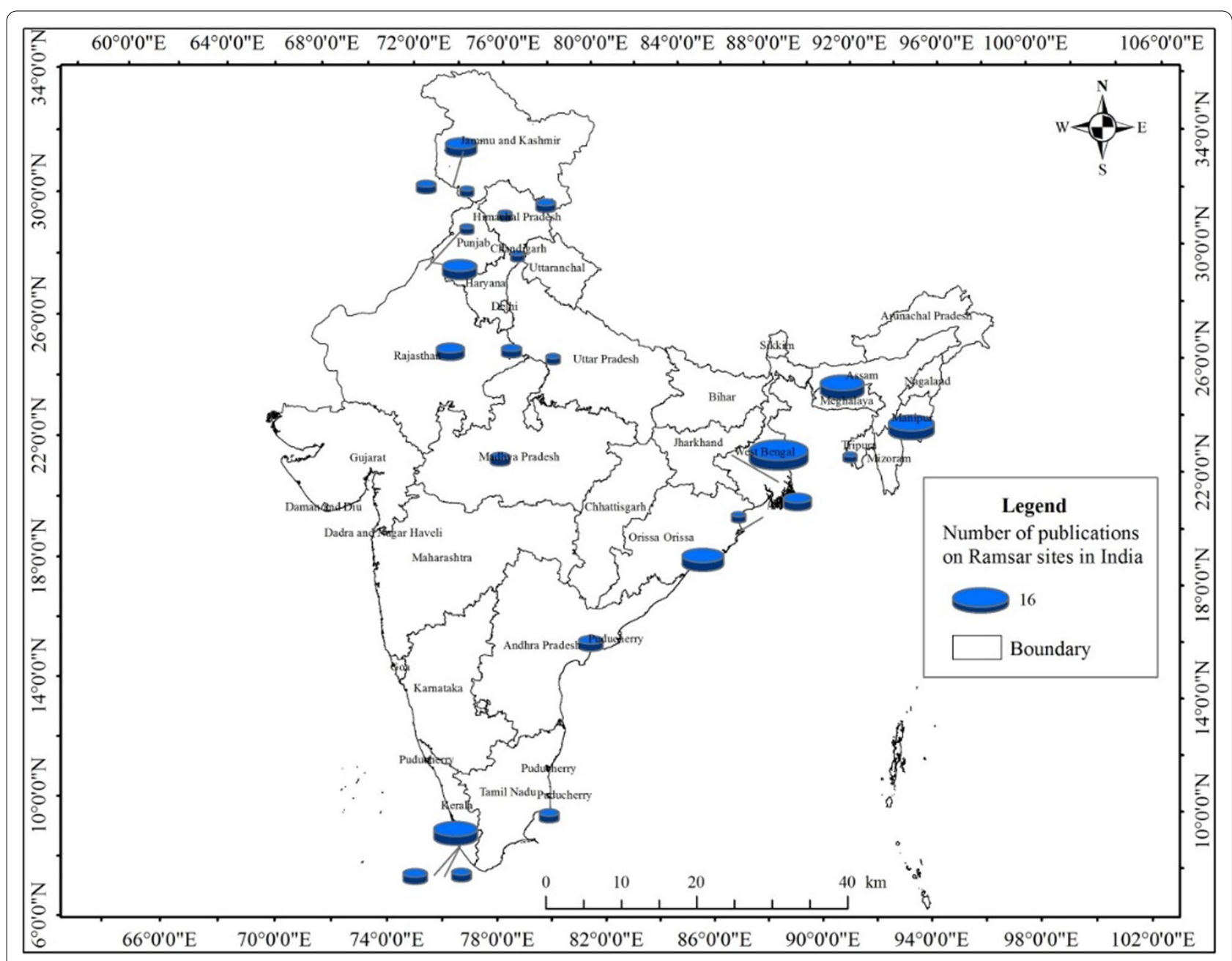

Fig. 630 years research publication on different Ramsar sites in India

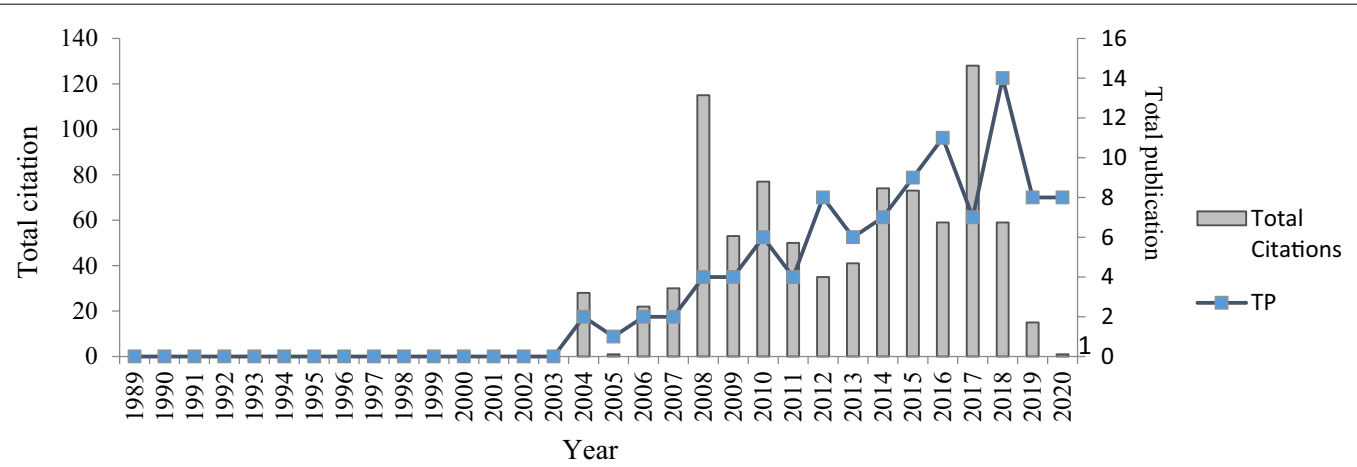

Fig. 7 Year wise publication output on Ramsar sites in India during 30 years 


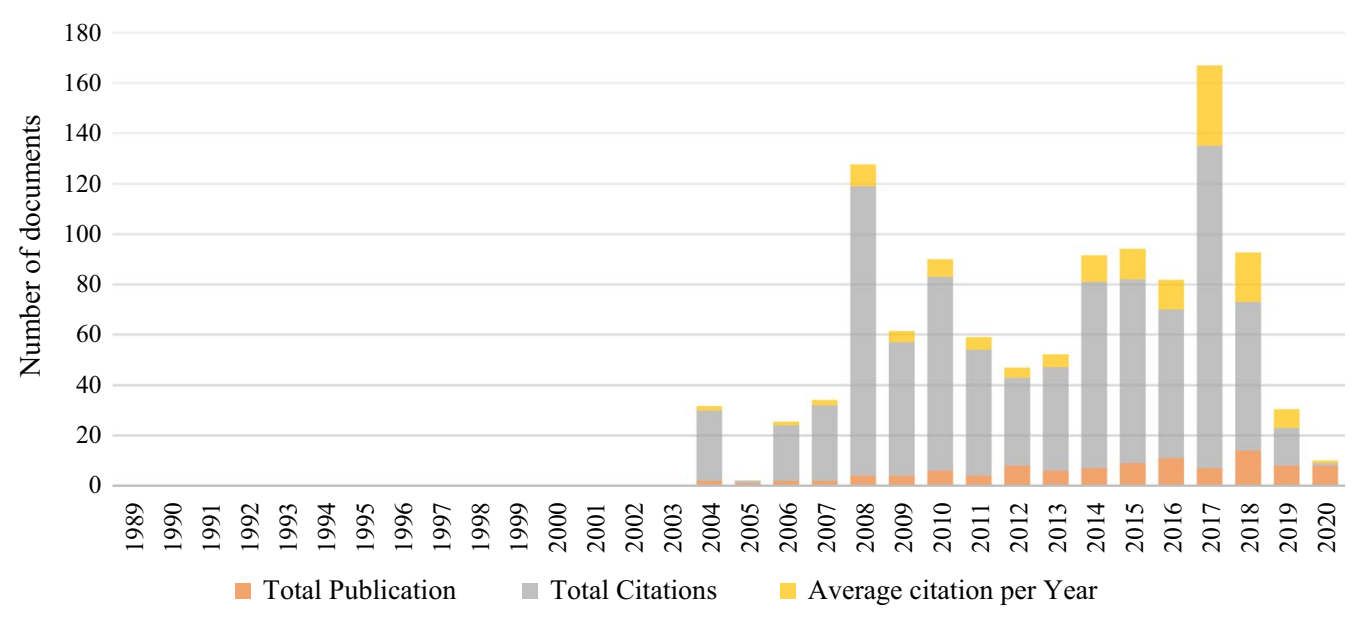

Fig. 830 years citation report of publications on Ramsar sites in India

1971 mainly to protect wetlands and their habitat with international collaboration were forcefully activated in 1975 (Zhang et al. 2010). However, from the beginning of twentieth century, research on this topic has dynamically increased worldwide (Koerselman and Meuleman 1996; Richardson 1994; Zhang et al. 2008). Even in India, the growth of publication and document citation proves that within a time span from 2004 to 2020, this field has become one of the dynamic areas of research interest among environmentalists (Fig. 8).

\section{Distribution of journal based on the subject area}

In this study, the distribution of different subject categories of the published journals has been classified. Among 103 documents, more than 20 distinct research areas have been identified where wetland or studies related to Ramsar sites in India have been published within last
30 years. Figure 9 shows, that the maximum number of records has been categorised under the research area of environmental sciences ecology $(58.25 \%)$ as the growing environmental and societal importance of wetland strengthens the researcher's interest in worldwide. Other than that, water resources (9.71), geology (8.74), marine freshwater biology (8.74), fisheries (6.80), oceanography (5.83) have also been observed as a dominant subject category where the researches about Ramsar sites in India have published. Such a diverse nature of research category indicates, wetland related studies in India has not only been published in environmental or water resources based journals but also communicated in chemistry (2.91), engineering (2.91) even in biotechnology applied microbiology (1.94) oriented journals.

In this regard, research related to Ramsar sites in India can be considered as a multi-disciplinary subject area

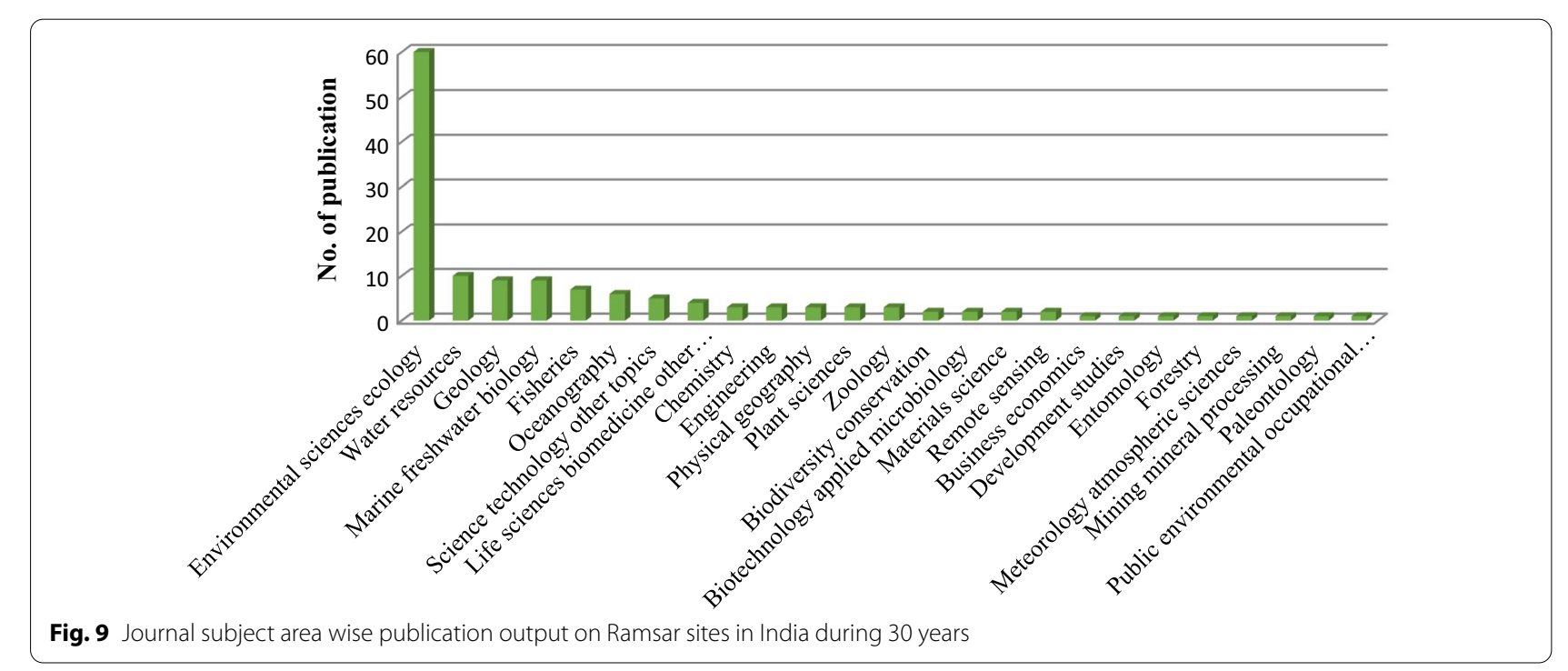


where interested readers can gather knowledge from different kind of categorised journals from different perspectives.

\section{Keyword analysis}

A network analysis map has been prepared based on the co-occurrence of all keywords used in Ramsar sites related studies in India. In recent years, keywords analysis in bibliometric studies plays an effective role to evaluate the information about present research trend in any research areas (Chiu and Ho 2007). It can reveal the content of the paper in a compactly.
Here, VOSviewer software has been used to execute such analysis because of its powerful visualising potentiality (Aibar et al. 2019). Only more than 2 times used keywords were taken into consideration. During the study period about 62 keywords were identified on Ramsar sites publications (Fig. 10). As per the size of bubbles which denotes the frequency of co-occurrence, "Ramsar site" ranked 1st followed by "India", "wetland", "wetlands", "remote sensing" etc.

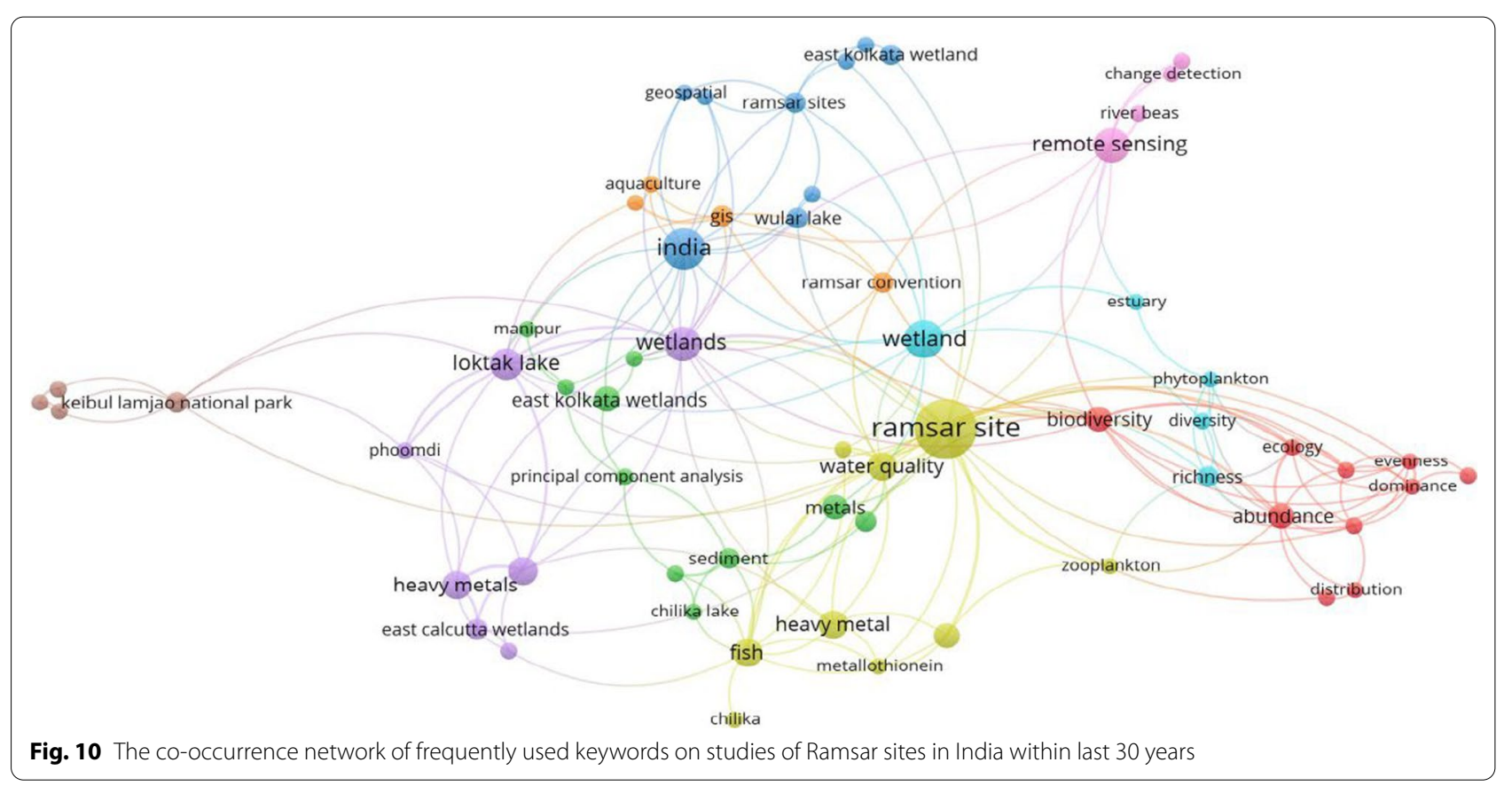

Fig. 10 The co-occurrence network of frequently used keywords on studies of Ramsar sites in India within last 30 years

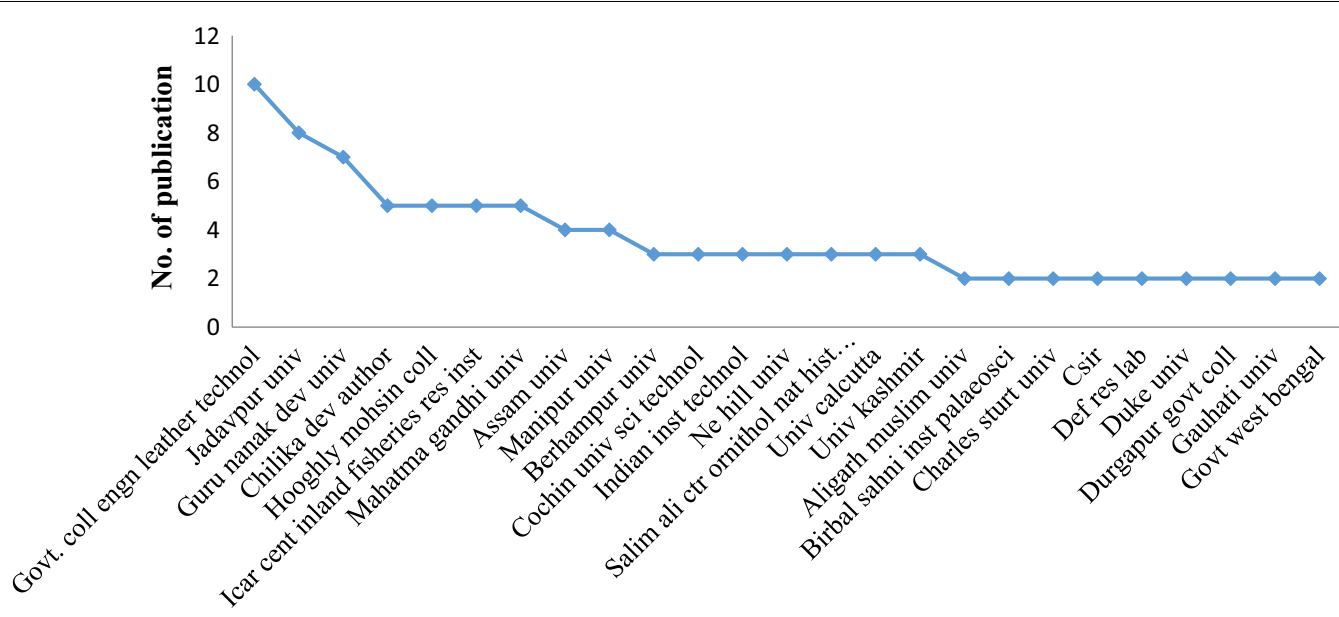

Fig. 11 Institute wise research publications on Ramsar sites in India during last 30 years 


\section{Productive institutions}

Productive institutions in terms of maximum publication on wetland or Ramsar sites in India have been estimated here and represented in Fig. 11. The majority of Indian institutions have got the highest ranking in publishing the maximum number of work on Ramsar sites. Among the 25 productive institutions, the top two institutions are from West Bengal i.e., Government College Engineering Leather Technology (9.71\%) and Jadavpur University (7.77\%), where the third institution Guru Nanak Dev University (6.80\%) has located in Amritsar, Punjab. In case of the present work is concerned, most of the institutions are from West Bengal, India like Berhampore University, University of Calcutta, and Durgapur Government College etc. Such kind of research interest among the Indian research may create more awareness regarding the conservation and management of Ramsar sites in India.

\section{Conclusions}

In this manuscript, a bibliometric investigation has been done on wetland research of Ramsar sites in India within time span of 1989 to 2020 . From the study, it has been found that number of wetland is highest under the areal extent of 1001-25,000 ha which are having the highest risk from ecological degradation. To understand such research potentiality of wetland at an international and national level and to broaden its environmental value among the locals, this study has been executed. The data required in the study have been extracted from the Web of Science online database, where almost 103 numbers of publications were sorted out. Articles were the most dominant type of document in this research area. Very few number of review observations were made on Ramsar sites in an Indian context. For better visualisation and interpretation, various kind of network analysis has been executed using the VOSviewer software. Other than that various graphical and schematic representations have also been taken here to represent various aspects of research outputs within the last 30 years. As per the annual trend of publication shows the peak of research publication and the score of citation has been started from the year 2004 and $98.06 \%$ of research are under the research articles. The country-wise representation depicts India has been recognized as the most productive country not only for the number of publications but also for the international collaborative works and East Calcutta Wetland of West Bengal grabbed the main attention. Most of the publication has been carried out in the environmental sciences ecological category. Besides that, most used keywords were also documented which shows the core research area on wetland studies.
Despite such deliverables, wetlands are very much threatened by different anthropogenic factors, which not only diminish wetlands but also loss of species, floral and faunal diversity even improper environmental restoration is also very much prominent. In this regard, some societal beneficial research outcomes will be very much appreciable.

\section{Acknowledgements \\ The authors would also like to express their sincere thankfulness to the digital library of Jadavpur University for providing the necessary facilities for carrying out the present study. In addition, the authors also acknowledge the computer laboratory of School of Water Resources Engineering, Jadavpur Uni- versity for providing the necessary facilities to access all the GIS and statistical software.}

\section{Authors' contributions}

The idea for the article has been generated by MBR. Literature search, material preparation, data analysis and mapping and the first draft of the manuscript have been prepared by SN. The introductory part of the manuscript has been written by SH. PKR and MBR have gone through the entire manuscript for necessary modifications. All authors read and approve the final manuscript.

\section{Funding}

Not applicable.

Availability of data and materials

All data generated or analysed during this study are included within the manuscript.

\section{Declarations}

Ethics approval and consent to participate Not applicable.

\section{Consent for publication \\ Not applicable.}

\section{Competing interests}

The authors declare that they have no conflict of interest.

\section{Author details}

'Department of Geography, Women's College, Calcutta, Kolkata, West Bengal, India. ${ }^{2}$ School of Water Resources Engineering, Jadavpur University, Kolkata, West Bengal, India.

Received: 8 April 2021 Accepted: 20 February 2022

Published online: 07 March 2022

\section{References}

Aibar LF, Mariné MGB, Terceño A, Pié L (2019) A bibliometric and visualization analysis of socially responsible funds. Sustainability 11:2526

Bassi N, Kumar MD, Sharma A, Pardha-Saradhi P (2014) Status of wetlands in India: a review of extent, ecosystem benefits, threats and management strategies. J Hydrol Reg Stud 2:1-19. https://doi.org/10.1016/j.ejrh.2014 07.001

Biswas Roy M, Kumar Roy P, Samal NR, Majumdar A (2012) Socio-economic valuations of Wetland based occupations of lower gangetic basin through participatory approach. Environ Nat Resour Res 2(4):30-44

Biswas Roy M, Chatterjee D, Mukherjee T, Kumar Roy P (2016) Environmental threat to wetland bio-diversity on migratory bird: a case study of periurban area of West Bengal. Asian J Curr Res 1(1):30-38

Brix H (1994) Use of constructed wetlands in water-pollution control—-historical development, present status, and future perspectives. Water Sci Technol 30(8):209-223 
Chandra K, Bharti D, Kumar S, Raghunathan C, Gupta D, Alfred JRB, Chowdhury BR (2021) Faunal Diversity in Ramsar Wetlands of India. Jointly Published by the Director, Zoological Survey of India and Wetland Division, Ministry of Environment, Forest and Climate Change, Government of India, pp $1-292$

Chen SR, Chiu WT, Ho YS (2005) Asthma in children: mapping the literature by bibliometric analysis. Rev Fr Allergol Immunol Clin 45(6):442-446

Chiu WT, Ho YS (2007) Bibliometric analysis of tsunami research. Scientometrics 73(1):3-17

Davidson NC (2016) Ramsar convention on wetlands: scope and implementation. In: Finlayson C et al (eds) The wetland book. Springer, Dordrecht. https://doi.org/10.1007/978-94-007-6172-8_113-1

Froend RH, Horwitz P, Sommer B (2016) Groundwater dependent wetlands. The wetland book, pp 1-12. https://doi.org/10.1007/978-94-007-6173-5_ 246-1

Gardner R, Connolly K D, Bamba A (2008-2009) African wetlands of international importance: assessment of benefits associated with designations under the Ramsar Convention. 21 Georgetown International Environmental Law Review 257

Griffin PJ, Ali SH (2014) Managing transboundary wetlands: the Ramsar Convention as a means of ecological diplomacy. J Environ Stud Sci 4(3):230-239. https://doi.org/10.1007/s13412-014-0173-0

Hsieh WH, Chiu WT, Lee YS, Ho YS (2004) Bibliometric analysis of patent ductus arteriosus treatments. Scientometrics 60(2):205-215

Kingsford RT, Bino G, Finlayson CM, Falster D, Fitzsimons J, Gawlik DE, Murray NJ, Grillas P, Gardner RC, Regan TJ, Roux DJ, Thomas RF (2021) Ramsar wetlands of international importance-improving conservation outcomes. Front Environ Sci 9:643367. https://doi.org/10.3389/fenvs.2021.643367

Koerselman W, Meuleman AFM (1996) The vegetation N: P ratio: a new tool to detect the nature of nutrient limitation. J Appl Ecol 33(6):1441-1450

Lal R (2008) Carbon sequestration. Philos Trans R Soc B 363(1):815-830

Mitsch WJ, Gosselink JG (2007) Wetlands, 4th edn. Wiley, New York

MoEFCC (2020) Ramsar sites of India-factsheets. Ministry of Environment, Forest and Climate Change, Government of India

Nath R, Nath D, Li Q, Chen W, Cui X (2017) Impact of drought on agriculture in the Indo-Gangetic Plain, India. Adv Atmos Sci 34(3):335-346. https://doi. org/10.1007/s00376-016-6102-2

Prasad SN, Ramachandra TV, Ahalya N, Sengupta T, Kumar A, Tiwari AK, Vijayan VS, Vijayan L (2002) Conservation of wetlands of India-a review. Trop Ecol 43(1):173-186

Ramsar (2020, March 28). Ramsar Sites Information Service retrieved from https://rsis.ramsar.org/

Rawat BS (2018) India wetlands review 2017: important Governments decisions. Important Government Decision SANDRP, pp 1-10

Richardson CJ (1994) Ecological functions and human values in wetlands: a framework for assessing forestry impacts. Wetlands 14(1):1-9

Shah P, Atisa G (2021) Environmental education and awareness: the present and future key to the sustainable management of Ramsar convention sites in Kenya. Int Environ Agreem. https://doi.org/10.1007/ s10784-021-09534-7

Van Eck NJ, Waltman L (2010) Software survey: VOSviewer, a computer program for bibliometric mapping. Scientometrics 84:523-538

Whitehouse NJ, Langdon PG, Bustin R, Galsworthy S (2008) Fossil insects and ecosystem dynamics in wetlands: implications for biodiversity and conservation. Biodivers Conserv 17(9):2055-2078

Xi Y, Peng S, Ciais P, Chen Y (2020) Future impacts of climate change on inland Ramsar wetlands. Nat Clim Change. https://doi.org/10.1038/ s41558-020-00942-2

Zedler JB, Kercher S (2005) Wetland resources: status, trends, ecosystem services, and restorability. Annu Rev Environ Resour 30(1):39-74

Zhang L, Scholz M, Mustafa A, Harrington R (2008) Assessment of the nutrient removal performance in integrated constructed wetlands with the selforganizing map. Water Res 42(13):3519-3527

Zhang L, Wang MH, Hu J, Ho Y-S (2010) A review of published wetland research, 1991-2008: ecological engineering and ecosystem restoration. Ecol Eng 36:973-980. https://doi.org/10.1016/j.ecoleng.2010.04.029

\section{Publisher's Note}

Springer Nature remains neutral with regard to jurisdictional claims in published maps and institutional affiliations.

\section{Submit your manuscript to a SpringerOpen ${ }^{\circ}$ journal and benefit from:}

- Convenient online submission

- Rigorous peer review

- Open access: articles freely available online

- High visibility within the field

- Retaining the copyright to your article

Submit your next manuscript at $\boldsymbol{\nabla}$ springeropen.com 